\title{
Study on the Evaluation Index System of Innovation Education in Colleges and Universities
}

\author{
Chunyang Wang \\ School of Arts, East China University of Technology, China
}

Keywords: Education innovation; Evaluation index; System; Study; Higher school

\begin{abstract}
In twenty-first Century, the theme of social development is innovation, and in the field of education, the innovation of higher education has been prompted in recent years, but the effect is not very significant. This is not only a traditional influence, but also a social atmosphere, but the lack of evaluation mechanism of innovation education restricts innovation. The perfection of the mechanism of innovative education evaluation need to define the basic purpose, adhere to the basic principles of the evaluation of innovative education. Build this evaluation criteria system of innovative education in modern colleges and universities in the respects of innovation concept, personnel training, and teachers, the arrangement of course, the activities and economic security
\end{abstract}

\section{Introduction}

Innovation has always been the main force to promote the social civilization and human progress, innovation as the theme of the activities. Innovative talents are specific factors who promote social progress through a series of new activities. Especially the arrival of the era of economic knowledge, it more needs talents with a sense of innovation to achieve our more ideals with the help of the innovation of theory and practice. While the university, as the main source of innovation oriented talents, the development of innovative education and the cultivation of professional talent with innovative spirit are very important missions, which have been clearly defined in the law of higher education in China. In recent years, the innovation education in Colleges and universities has been prompted all the time, but the effect is not much significant, which has been influenced by the traditional concept social atmosphere, but the lack of innovative education evaluation of the mechanism is more strongly restricted the development of innovative education. How can we integrate the existing education system into innovative factors? The innovative education evaluation should be carried out comprehensively from the curriculum, the concept of ascension and the carry out of practical activities, which is the focus of innovation and education in Colleges and universities.

\section{Definition of the Evaluation of Innovative Education}

The Connotation of Innovative Education and Innovation. The so-called innovation is a concept which is used in the industrial production as early as nineteenth Century, with the progress of modern science and technology and the change of management requirements, the innovation is also gradual applied in the domain of management and the technology, and also applied in the education domain through its development. All of the fields, including education take innovation as a coping strategy, that 'a new way playing a useful role'. The main challenge of innovation action is to create wealth of resources in response to the new situation. "The connotation of innovation is affected by the purpose, the regularity of the change, the novelty and the development. As a result, the concept of the development put forward innovative education and education innovation, which is a new concept of education and arises with the rise of knowledge economy. Through the overview of the development of philosophy of education in the history of China, which develop mainly from the "moral, intellectual, physical all-round development" and to the union of "moral, intellectual, physical and aesthetic, then to talent with overall quality, and from "special talent" to "creative talents, we can see that more and more people focus on value and effect to society, but not limited in some aspects of the personal development. The core of "innovation" requires that education 
innovation is the core of innovation thinking, innovation consciousness, innovation personality and innovation education, and the transfer of auxiliary position of knowledge and technology.

Definition of the Evaluation of Innovative Education. The evaluation of innovative education is based on the specific evaluation criteria and use scientific, objective and effective evaluation means and methods. The current goal is still activities of innovative education in a time, such as the effectiveness of innovation and comprehensive analysis of education system, which improve the educational value of the activities of innovation and reconstruction. The analysis of the collection and information system is the premise and base; concrete, objective and effective evaluation system is the based on the evaluation criteria of education evaluation; scientific, objective and effective evaluation method is the guarantee of education evaluation. Fundamentally speaking, the education assessment is based on the analysis of the value of the judgment based on the facts. Fact judgment is the premise, the key of which is to find out the facts, especially in the policy evaluation. In fact, the judge is a preliminary assessment on the work of Education. Value judgment is the ultimate goal of education evaluation which is based on the fact that improving education ideas through the assessment, and understand and change the state of education objectives.

\section{The Main Reasons for the Formation of Innovation Education in Colleges and Universities}

The Urgent Need of Higher Education Reform. In the era of knowledge economy, the mode of higher education is to get rid of the elite higher education and traditional infusion style and have a popular trend. Under the new situation of higher education reform, the orientation is to organize the high quality workers, improve model of the process. The University should take the cultivation of innovative talents as the goal, fully mobilize the enthusiasm of the educated, so that they obtain a comprehensive development of practical ability in innovation, innovative thinking, We should reflect on these elements, and make it to be the power prompting the reform of higher education.

Innovative Education Needs to Be Standardized. At present, universities continue to promote innovative education, but the effect is not significant, specifically, the standardization of the specific implementation of innovative education has not yet entered the stage, especially compared with developed countries, innovative education ideas, curriculum setting, teachers respect, the Security mechanism of China's University has a big gap. The standard of innovation education is not only to reach a certain level, but also to improve the software in the education system. Namely, a mature system needs to improve the adaptability of the system through constant feedback mechanism. As a feedback mechanism, the evaluation of innovative education evaluates the index by norm of innovation education.

An Urgent Need to Develop Innovative Talents in Universities. Innovative talent mainly refers to a kind of high-level talent different from traditional personnel. It usually refers to highquality talents who have extraordinary sense of innovation, excellent creative thinking and awesome creative spirit and strong innovative ability and can obtain many innovations, whose core characteristics is that the talent has a good creative thinking, which is standard capacity of innovative practice, marking the realization of innovation. Innovative talent is assessed comprehensively and the specific content should include the will and the spirit needed, innovation, all aspects of innovation, these elements need to be assessed by innovative education to get feedback and improve, promote the cultivation of innovative talents.

\section{The Principle of Establishing the Evaluation Index System of Innovation Education in Colleges and Universities}

Be Sure to Highlight the Innovative Education. From the perspective of the subject and the receptor, innovative education includes two aspects: contents of innovative education, innovative education methods. The former is to reflect through innovation of educational environment (innovation atmosphere, recognition of innovation, innovation, and innovation conditions), security system (improving the hardware, equipment, investment in the experimental funds, etc.) and teachers and other indicators, which can set the curriculum by the cultural indicators, the concept of 
innovation including the innovation of the education objectives, education, innovation and education evaluation of the concept of innovation to express system, foster innovation and education of teachers, etc. In the process of establishing the evaluation system of innovative education in Colleges and universities, we should highlight the various indicators including the above-mentioned innovative education, innovation and education objectives.

Combine the Indicators of Guidance with Policy. The index of policy direction is a policy guidelines formulated by country or region to evaluate comprehensively the implementation. In fact, the perpetrators shall be the independent third party of the main administrative departments of education.

In order to meet the basic evaluation of educational evaluation the fact, targets set by policy indicators is the policy of education, so as to promote the assessment; the index is more flexibly focusing on the value judgment, mainly by the educational philosophy, embodied in the spirit of innovation and education, improve awareness, ability and other indicators, whose aim is to determine the value of the guide through in-depth innovative educational philosophy.

Combine the Characteristics with Common Indicators Closely. Common working index is the innovation of the educational environment, the cultivation of innovative ideas and other innovative educational subjects or indicators reflect the external factors, the index of different regions, different disciplines of professional (integrated, humanities, science and Engineering), combined with the actual development of the region's own educational objectives of the main characteristics of the assessment. The innovation education evaluation should insist on the common and the characteristic, combine to advance the development of the characteristic work.

Combine the Stage Evaluation and the Annual Evaluation Closely. In the evaluation system of higher education innovation, we must adhere to the principle of the combination of the annual evaluation and assessment, and focus on the key of the work has a strong flexibility, completed the evaluation index of this year's annual assessment objectives; work focus is the evaluation of the effectiveness of the evaluation stage, with strong stability, performance evaluation stage of the main objectives.

\section{Implication of the Construction of the Evaluation Index System of Innovation Education}

In establishing the evaluation index of innovation education, we should take the characteristics of higher education innovation into consideration. Education as a kind of advanced knowledge transfer is higher, to cultivate advanced specialized personnel of teaching activities, in addition to work with innovative education work have common features, common law must follow, but also have the characteristics of different from the general education process. Therefore, in the innovation of education literature and experts' effective innovative education work as an evaluation index of the characteristics of higher education innovation behavior, the first reference, the evaluation of innovative educational content thus established. We can divide the innovation education into four grades, good, good, general and poor. In order to quantify, it can be more scientific and rational use of. As the score will be converted into different grades, not only for school innovation education as a whole to evaluate, but also can be used alone, from a specific assessment to determine the specific location of the innovative education in various aspects seem to be targeted to improve and improve, in order to better promote innovative work in Colleges and universities.

\section{Evaluation Index System of Innovation Education in Colleges and Universities}

Innovation Idea. In the whole process of educational practice, the cultivation of innovative ideas is the main task of the modern social education idea reform, and the specific issues are implemented through innovative education, innovative education, innovative spirit, innovative thinking, innovative and innovative personality, these elements should be reflected in the evaluation index system of innovative education in Colleges and universities.

Personnel Training. Talent training is the most effective factor for the evaluation of innovation education. It mainly refers to the combination of theoretical knowledge and concrete practice, 
which can be applied to the practical work. The index mainly through the annual review of the amount of innovative talent to the community, the establishment of a regular feedback mechanism, the use of units and teaching staff evaluation mechanism to improve the effectiveness of innovative education. For the cultivation of innovative talents, the main goal is to promote the development of talent, so that it can have the actual needs of the community and the future work unit, fully demonstrated their own learning, through their own efforts to contribute to the economic development of the whole society. Therefore, the index should be set up to study their innovative talents, strengthen the innovation education and the needs of the actual combination of the actual situation of the combination of personnel to provide a realistic environment for innovation.

Faculty. As a teaching aspect, it is possible to play the main role of the teacher in the education innovation, which may include: Teachers' professional background, the theoretical issues of the frontier research, and the extent of the practical application of the teaching staff. Through the assessment, to improve the teaching of theory and practice, to strengthen the ability of social integration with social units, teachers and their own teachers, teachers will eventually be transformed into innovative education.

Activities. Innovative educational activities complement classroom teaching, the number can be taken in this regard through vocational training courses, seminars, lectures and other activities of the people, to participate in comprehensive assessment of the most cutting-edge, intended to through these activities, to grasp multi-channel information, innovative teaching methods and collective guidance, in order to form a creative thinking and education.

Security Mechanism. All aspects of innovative education need to match the mechanism, the conditions of protection. The evaluation of this aspect includes: the ownership and use of laboratory equipment, the establishment of the investment curriculum system, the innovation of education funds, the organization of teaching, and the emphasis on innovation education, innovation education and the atmosphere and so on.

\section{Conclusion}

Above all, the innovation education evaluation as a very systematic project, the construction of the index system and no fixed pattern, we must according to the actual situation in the process of evaluation to carry out gradually improve, in strict accordance with the actual needs of the community to achieve the basic purpose of education. Therefore, in the process of establishing the evaluation system of innovation education, the research must be sustainable, and need to cooperate closely with the education department. The evaluation of innovative education in Colleges and universities is mainly to promote and strengthen the effectiveness of innovation education in Colleges and universities. To Finding out the shortcomings in the practice of innovation education through the evaluation and to improve the work, to plug the loopholes, to complete the goal of innovation education, to promote the healthy, steady and sustainable development of institutions of higher learning.

\section{References}

[1] Mao Changjuan, Cui Lin. Analysis of innovative education evaluation in Colleges and universities and educational materials [J].2013,08:86-87+156.

[2] Wang Yunbo, Sun Yingjuan, Jinghong. The study on education system of innovation and entrepreneurship [J].Century bridge, 2015,03:65-67.

[3] Zhang Tianhua, Wang Xulong. The research on the development of teaching resources for innovation and entrepreneurship education in Colleges and universities[J]. Journal of Liaoning University of Technology (SOCIAL SCIENCE EDITION), 2015,04:75-78.

[4] BaiYun. The study on practical education for innovation and entrepreneurship education in Colleges and universities [J]. Chinese and foreign entrepreneurs, 2015,21:168. 
[5] $\mathrm{Yu}$ Wen. Innovation and entrepreneurship education in Colleges and universities the status quo and Countermeasures of [J].The road to success, 2015,19:10-11.

[6] Cao Yang. The research on innovation and entrepreneurship education in Colleges and Universities under the background of the transformation of economic development mode [D]. Northeast Normal University, 2014

[7] Chen Liang. Support for innovative entrepreneurship education in Colleges and Universities -Taking Nantong University as an example of [J]. technology vision, 2014,08:134+152.

[8] Wang Chengguo. The status of entrepreneurship education innovation of private colleges and Countermeasures [J]. Heilongjiang Shi, 2013,23:289.

[9] the innovation and entrepreneurship education [m]., Chen Jingliang-Fudan University Press 2012:125-129.

[10] The innovation and entrepreneurship overview [M]. Ni Feng - Higher Education Press - 2012: 145-147. 